\title{
5. Refugees between pasts and politics: sovereignty and memory in the Tampa crisis
}

\author{
J. Olaf Kleist
}

Were a conflicting event, the initiative of one or several members, or, finally, external circumstances to introduce into the life of the group a new element incompatible with its past, then another group, with its own memory, would arise, and only an incomplete and vague remembrance of what had preceded this crisis would remain.

- Maurice Halbwachs ${ }^{1}$

The citizen voice can be controlled by the control of migrants.

- Alastair Davidson ${ }^{2}$

On the morning of 25 August 2001, few Australians had heard of the merchant vessel Tampa. The Norwegian ship had left the port of Fremantle three days earlier and was on its way to Singapore. The next day, the Tampa rescued 439 people from a sinking boat, prompting a major shift in Australian refugee policies, sparking a major political controversy and turning around the ailing fortunes of the governing Liberal-National Coalition ahead of a federal election later that year. On the morning of 25 August, Melbourne's Age carried an article on its opinion page that would become far more relevant than its author, Hugh Mackay, could ever have anticipated. He warned:

When there is a lack of inspirational leadership, two things always happen. The community's focus narrows and turns inwards as people disengage from the national agenda and become almost exclusively concerned with local issues, and the vacuum created by the lack of social vision sucks a flood of vicious prejudice to fill the space. ${ }^{3}$

With much derogatory language already used against refugees, Mackay predicted that the Coalition would draw on racist prejudices against asylum-seekers during the forthcoming election campaign. Such rhetoric did indeed become a constitutive part of the Tampa debate. ${ }^{4}$ Still, this was by no means a new attribute of Australian discourse and could not fully explain the specific character of the debate. ${ }^{5}$ Although the event sent shockwaves through Australian society, it seems difficult to determine the distinct qualities that characterised the political changes of this event. I suggest that the response to the Tampa's rescue efforts 
modified the conception of sovereignty in a far-reaching manner, causing a new perception of citizenship, memory and the situation of asylum-seekers.

Sovereignty is not a fixed but a politically contested concept. Internally, it relates citizens to the State as the self-determination of people within a contained territory. Internationally, it circumscribes the territorial borders of a polity defined by its self-determination. The relationship of this inner and outer conception of sovereignty creates, as Giorgio Agamben argues, a paradox: they are the factual foundation of each other's potential to sovereign power. ${ }^{6}$ In other words, sovereignty is an existing contradictio per se: its limits define belonging and vice versa. Stateless people fall in between the sovereigns that make up the world of nation-states. For asylum-seekers, this is not only important with regard to the detention centres that Agamben writes about. To them, the sovereign is on the one hand the potential guarantor of rights and on the other an obstacle - as protective power over its subjects and its territory.

In the politics of the Tampa crisis, sovereignty's contradiction allowed a political shift that reconfigured its relationship to refugees: from excluding asylum-seekers from civil rights to excluding them from the claim to sovereign protection under human rights. This shift established a qualitative change in political action and debate. The implications of the policies implemented due to the crisis for refugees and the specificity of their exclusion can be illuminated by looking at the use of the past in parliamentary debates before and after the Tampa incident. The use of memories signifies shifting perceptions of belonging, sovereignty and refugees.

The relevance of the past for social belonging and political action was an important issue not only after, but immediately before the Tampa crisis. Right next to Mackay's op-ed article, the historian Janet McCalman reminded readers that '[t]eaching history safeguards the truth':

There are many reasons why history matters in a healthy and democratic society. Our understanding of the past - both in our own lives and in society - shapes our sense of identity and provides an accumulation of human experience to guide us in the present and for the future. ${ }^{7}$

Public life needed, she wrote, a trustworthy engagement with history. The past, however, is a very uncertain category that relies much on the circumstances in which it is remembered. Theories of social memory agree on the constructivist character of memories. ${ }^{8}$ This means, for one, that people remember the past selectively to find answers to current problems and, for another, that the act of remembering imagines a social group to connect the present with the past. ${ }^{9}$ If, however, the present determines the perception of the past, it determines how the social group is imagined too. Theories of memory have analysed the various roles of social memories, including the role of memory in political processes. ${ }^{10}$ 
I suggest that looking at how social memories are used can help us to understand the political shift that occurred in the debate about the Tampa in regard to Australian self-perception and its relation to refugees. In analysing parliamentary debates about refugee issues, I show that before Tampa the use of memories suggested a communal belonging and, in its political context, an unmediated understanding of sovereign action. As the response to refugees changed, the past, as it was employed in political debates, played a decisive new role. Now memories referred merely to isolated elements of sovereignty, leaving not only refugees in a position devoid of sovereignty, but citizens and the State. I argue that the distinct forms of memory and their application of sovereignty, as they emerge in this analysis, are related 'ideal types'. The qualitative change in the actions and attitudes towards refugees can be understood as the result of the government's use of sovereignty in the Tampa crisis and the resulting shift in the public significance of the described forms of memory. Ultimately, this confrontation of different forms of political memory before and after the crisis questions the legitimacy of sovereign state power over refugees.

\section{The old and the new of the Tampa crisis}

The unauthorised arrival of asylum-seekers was highly controversial long before the Tampa crisis occurred. Between 1992 and 2001, successive Australian governments responded to these arrivals by detaining all onshore asylum-seekers until their applications for a protection visa had been accepted or until they were deported. With arrivals increasing in the late 1990s, the number of detainees grew while the situation in detention centres deteriorated rapidly. On the one hand, riots, escapes and incidents of self-harm were causes of concern for the Howard Coalition Government; on the other hand, the ordeal of the detainees functioned as a barely concealed method of deterrence, with its implicit warning that suffering awaited those who attempted to subvert Australia's sovereign integrity.

Although the government failed in its attempt to reduce the number of unauthorised boat arrivals, it stuck to its tactic of deterrence through detention of 'illegal' immigrants. In April 2001, it introduced the Migration Legislation Amendment (Immigration Detainees) Bill 2001, the so-called 'strip-search bill', to give staff at immigration detention centres more powers. The bill was modified during that year and discussed in Parliament just as the Tampa crisis was unfolding. As more and more refugee boats arrived in Australian territory, the main response by Immigration Minister, Philip Ruddock, was to declare, as late as 23 August 2001, that more detention centres would be built. ${ }^{11}$ 'The Tampa changed those circumstances,' David Marr and Marian Wilkinson assert. 'Suddenly here was an opportunity for Howard to show Canberra was in control.' $^{12}$ Now, navy, police and security services became the preferred weapons to deter refugees from arriving by strengthening border protection. 
What was behind the sudden change from what Peter Mares calls a strategy of 'deterrence by example' - that is, the show of harshness and potential force - to 'deterrence by force', the use of the Navy and real force to prevent boats from entering the Australian migration zone? ${ }^{13}$ The answer, I propose, was flying at the stern of the Tampa.

As the Tampa sailed towards Australia under the flag of a sovereign state (Norway), the Australian Government finally had an appropriate counterpart to deal with 'boat people'. ${ }^{14}$ Until then, refugee boats could not be ordered (or expected) to respect Australian borders because they had no obligations to any sovereign state. Conversely, the Tampa, flying a sovereign flag, under international law, had to defer to Australia's legal jurisdiction in its territory. The Norwegian vessel did so, at least partially, and did not land its passengers at Christmas Island. With the Tampa following orders, Australian authorities assumed they were in a position to direct boats carrying refugees. According to Marr and Wilkinson, the government's initial response to the Tampa and the subsequent interception of refugee boats developed spontaneously rather than according to a detailed plan. ${ }^{15}$ Only after the Tampa's rescue effort did border security become the front line of refugee deterrence, sparking a major political controversy. Suddenly, by neglecting the special circumstances under which the refugees travelled on board the Tampa, it seemed possible to keep all refugees outside the migration zone through the use of real force.

In the beginning, the government, despite its intuition for popular moods, was possibly not fully aware of the implications regarding sovereignty, refugees and belonging. The swing in the pre-election polls towards the Coalition justified its actions. The delicate relationship between sovereign power and refugees, however, and its domestic implications with regard to citizens, should not be underestimated in comprehending the impact of the Tampa incident on Australian public debate and politics.

\section{Sovereignty and refugees (I)}

The Tampa affair precipitated a change in refugee policy and political discourse, but also in perceptions of the sovereign body politic. In the first days of the crisis, Ruddock, in statements to the media and to Parliament, was still committed to a policy of deterrence by example. To him, the introduction of new refugee legislation was 'crucial to ensuring that we reduce Australia's relative attractiveness', 16 while the deportation of unsuccessful asylum-seekers was regarded as 'a strong message to the world that Australia intends to fight people trafficking'. ${ }^{17}$ Australian refugee policies were not directed at subjects under Australian jurisdiction but at potential refugees who could neither be engaged nor specifically located. With the emphasis shifting from dealing with asylum-seekers on shore to protecting the borders against their arrival, the tone 
of the political debate also changed. When Howard first announced to the House of Representatives that the merchant vessel Tampa had picked up refugees who were on their way from Indonesia to Australia, he reiterated his mantra that it was Australia's right as a sovereign nation to determine who came into the country and under what circumstances. ${ }^{18}$ Within days, sovereignty changed from being the foundation of the polity that needed protection against stateless asylum-seekers to being the reason for policies to exclude refugees.

The new policy of deterrence by force seemed appropriate for the new situation. It was, however, founded on the basic contradiction of sovereign power. The Tampa's breach of Australia's territorial sea border off Christmas Island on the morning of 29 August prompted several responses. On the practical side, Special Air Service (SAS) elite troops intercepted the Tampa in inflatable Zodiac boats. In order to prevent the refugees from engaging Australia's protection obligations as a sovereign nation under the 1951 Refugee Convention, the boats did not fly Australian flags. ${ }^{19}$ At a first glance, this action appeared to invert the relation between refugees and border control. The refugees were on a huge ship under Norwegian jurisdiction while the Australian soldiers approached them in tiny vessels that did not display any sign of sovereignty. It seems the Australian troops were attempting to take advantage of the precarious position of stateless 'boat people' not affiliated to a sovereign. They were, however, Australian military forces, displaying the Australian flag on their uniforms and they acted on behalf of the sovereign in Australian territorial waters. Besides, the power relations were made obvious when armed Australian soldiers boarded the Norwegian ship. The captain had no choice but to let the SAS proceed with its operation. In the same instance, however, the refugees could not claim their rights to apply for asylum. The Australian soldiers were at once representatives of Australian sovereignty and not. Being subject to the power of sovereignty but having no rights to asylum posed a pertinent contradiction and a dilemma for the refugees.

This contradiction of sovereignty was also true in relation to the Norwegian ship and had been highlighted under different circumstances 20 years earlier. The UN High Commissioner for Refugees (UNHCR) argued in response to Indochinese 'boat people' who had been rescued in 1981 by cargo ships on the high seas:

While...there is a clear duty for ships' masters, their owners and their Governments to rescue asylum-seekers at sea, there is no obligation under international law for the flag State of a rescuing vessel to grant durable asylum to rescued refugees. It is, of course, correct that by boarding a vessel, the refugee comes under the jurisdiction of the flag State which is considered to exercise jurisdiction over the ship on the high seas. ${ }^{20}$

The responsibility for asylum-seekers rescued at sea has since been disputed and remains unresolved. ${ }^{21}$ Due to the ambiguities surrounding the issue of 
sovereign power on the high seas, having powers of jurisdiction on the one hand and the absence of obligations to asylum-seekers on the other, rescued refugees are caught in a legal limbo.

Refugees aboard the Tampa were thus 'caught', not only physically but legally between two sovereign powers, Australia and Norway. The situation reflected the potential for both conflict and cooperation between two overlapping sovereign entities: a Norwegian boat within Australian territory. More importantly, the engagement allowed Australian executive powers to position refugees as legal objects, in between the two powers, and to deal with them accordingly.

As a legal reaction to the border breach by the Tampa and the refugees aboard, and in response to the apparently delicate contradiction of sovereignty, the government introduced the Border Protection Bill 2001 into Parliament. This proposed to legalise the removal of unwanted ships from the territorial sea (Sections 4-6), to render any actions of Australian officers in regard to those ships not reviewable in any Australian court (Section 7) and to invalidate any application for a protection visa from aboard such a ship (Section 9). ${ }^{22}$ It was to apply retrospectively from the morning of 29 August, just before the SAS boarded the Tampa (Section 11). When Prime Minister Howard informed the Opposition of the bill, 40 minutes before it was to be debated in the House of Representatives, he asked for it to be approved in both chambers that same night. After a lengthy debate, however, the Senate, in which the government parties did not have a majority, rejected the bill.

In Parliament, the dispute centred on the issue of where sovereignty lay within the body politic. Howard underlined the importance of the bill by saying that '[i]t is essential to the maintenance of Australian sovereignty, including our sovereign right to determine who will enter and reside in Australia'. ${ }^{23}$ Every breach of the Australian border seemed to question the authority of the government and therefore undermine Australia's sovereignty. Senator Robert Hill (Liberal) declared: 'Surely, a reasonable person would say that the Australian government should have all necessary powers to do what is necessary to protect the integrity of Australia's borders. ${ }^{24}$ It seemed unreasonable not to use all force available to the government in order to re-establish the sovereignty that seemed to be violated by the Tampa's border breach. The government's interpretation, however, reduced sovereignty to only the executive power within Australian territory, represented of course by the government itself.

The opposition parties rejected the bill for several reasons - one being that the government had not consulted them about the legislation ahead of its introduction. Apart from such formal objections, the Labor Party doubted the severity of the situation. The Leader of the Opposition, Kim Beazley, rejected the government's alarmism, saying that 'we do not face in these circumstances 
a national catastrophe; we face a serious problem'. ${ }^{25}$ While the Opposition agreed with the government on Australia's sovereign right to determine questions of immigration, it did not equate sovereignty merely with the executive power of the government but with the institutions of the State. For the Opposition, it was not so much the refugees who were a threat to sovereignty; rather, it considered the bill a danger to Australian sovereignty because it undermined the balance of power. That actions committed under the law proposed by this bill would not fall under Australian jurisdiction was considered a threat to the balance of power and therefore, as one parliamentarian suggested, the bill might even undermine the constitution. ${ }^{26}$ Overall, the debate about a bill designed to prevent refugees from entering Australian territorial waters turned into a debate about the legal parameters of the State's sovereign power.

The problem of sovereignty in relation to refugees is not new. Hannah Arendt describes this problematic relationship in her 1948 book The Origins of Totalitarianism. ${ }^{27}$ The nation-state, she argues, is based on two doctrines: the universal rights of man - or human rights - and the sovereignty of people as citizens. Refugees, who lose the protection of their state, are not citizens anymore but can still claim human rights - in principle at least. With regard to refugees, the doctrines of the nation-state are therefore separated. This has grave consequences for the idea of sovereignty, as Agamben explains:

If in the system of the nation-state the refugee represents such a disquieting element, it is above all because by breaking up the identity between man and citizen, between nativity and nationality, the refugee throws into crisis the original fiction of sovereignty. ${ }^{28}$

Sovereignty presupposes a solid concept of self-determination with a clear distinction between those who belong and those who do not. It has, however, both a civic foundation, originating from people's self-rule as citizens, and a universal foundation, the universal recognition of people's right to sovereignty. In respect to refugees, however, these two concepts collide because stateless people reveal, qua their existence, the fiction of the right to sovereignty. For a state, this means, on the one hand, that it has an obligation to recognise the refugees' universal right to sovereignty, because the State itself is based on this recognition; on the other, it can do so only under its sovereign powers, which by definition are limited to citizens. With regard to refugees, a state has to be a sovereign and a non-sovereign power at the same time, thereby undermining its legitimacy.

The challenge of refugees to the government was (and always is) to translate this 'fiction of sovereignty' into politics. In 1992, the Labor Government under Paul Keating confronted this dilemma by enforcing the distinction between citizens possessing and non-citizens not possessing civil rights under a sovereign power by introducing administrative immigration detention for non-citizens who did 
not hold a valid visa. That same year, the High Court ruling on immigration detention in Chu Kheng Lim vs Minister for Immigration, Local Government and Ethnic Affairs asserted the distinction of this policy, according to which those who were not Australian citizens had no claims against administrative incarceration. $^{29}$ The policy and the ruling affirmed in principle, however, that refugees in detention retained the human right to claim asylum within a sovereign territory.

What was new after Tampa was that refugees were denied civil rights and their human right to asylum. Australian authorities now completely separated sovereignty from universal rights. For one, they acted as a sovereign power against the Norwegian vessel, practically detaining the stateless refugees at sea. With the Border Protection Bill 2001, the government attempted to legalise this approach. Furthermore, the authorities prevented the refugees from reaching the migration zone or from applying for asylum by other means. ${ }^{30}$ They confronted refugees with sovereign power without conceding that the new arrivals had any rights under this power, especially the right to claim asylum. The Migration Amendment (Excision from Migration Zone) Act 2001 would later establish exactly this separation in the distinction between territory and migration zone. In order to deal with stateless people, the government separated human rights not just from citizenship but from sovereignty altogether.

Conversely, this meant disaggregating sovereignty from the expression of pure power directed at stateless people when preventing them from claiming asylum. This had implicit repercussions for Australian sovereignty, rearranging the relationship between Australian citizens and the State. In the parliamentary debate about the Border Protection Bill 2001, this new situation was interpreted as denoting a shift in sovereign power. The Opposition pointed to the danger of separating sovereign powers from rights, not just in relation to refugees but to all citizens. Some parliamentarians noted that sidelining the judiciary and giving unlimited powers to the executive with regard to unwanted vessels in the territorial sea would undermine the rule of law and the balance of power within state institutions. ${ }^{31}$ Since the balance of power is to safeguard democratic self-rule, an executive power without institutional checks and balances would not only be uncontrollable with regard to refugees, it would separate the power of the State from the broader principle of sovereignty.

Sovereignty, the Opposition's remarks implied, was a question not just of executive power but of all state institutions; yet, neither was it a privilege of state institutions as a means in itself. The sovereignty of the nation-state is, as Arendt observes, intrinsically bound to citizenship. The Opposition was concerned, as Labor MP Robert McClelland outlined in a later debate, that the implications of cutting off the control mechanism between the citizenry and the sovereign power would extend beyond stateless people. Contemplating the 
Opposition's rejection of the border protection legislation, during the parliamentary debate on the so-called 'Pacific Solution', he pointed out:

Clause 6 [of the Border Protection Bill 2001] gave power for a Commonwealth officer, or a person assisting an officer, to return to a ship 'a person' who was on board the ship. Of course 'person' could mean an Australian citizen, a citizen of the United States, Canada, Great Britain or from anywhere in the world-'a person'; a human being. ${ }^{32}$

The goal of deterrence by force, which, in the Opposition's view, the Border Protection Bill 2001 failed to deliver, was of course intended to target unprotected humans without endangering citizens. Indirectly, the Opposition wanted to retain the old model based on the fiction of sovereignty without human rights.

The imaginary distinction between a migration zone and a territory, established during the Tampa crisis, created two seemingly distinct powers in regard to refugees: one within the migration zone being checked and approachable as a sovereign, and another outside being apparently pure power. This division, employed as a policy of deterrence by force, placed the executive power of the State in a new and unchecked situation outside the sphere of sovereignty. As a result of neglecting the sovereign source of its power, the government was able to use force outside the migration zone without exposing itself as a sovereign on which refugees could have called for protection. This meant excluding refugees' access to sovereignty and splitting governmental power from citizenship. If sovereignty demarcates not only the reach of power but the confines of responsibility then Australian territorial integrity is defined by 'pure' governmental power and no longer by the principle of sovereignty. In the government's policies - and legally since the Migration Amendment (Excision from Migration Zone) Act 2001-sovereignty extended to the migration zone only but not to Australia's territorial seas and some excluded islands. This new understanding of sovereignty, which was created to exclude refugees, in turn had an immense impact on Australian self-conceptions, as expressed through social memories in the debates on refugee policies.

\section{Sovereignty and memories (I)}

Whenever Members of Parliament debated issues concerning refugees they also negotiated Australian inclusion in general. The question of sovereignty is just one way of relating these two issues; it is the legal perception of the refugee issue and of the issue of belonging. Belonging to a sovereign society has also been expressed through memories in terms of tradition, especially before the Tampa crisis unfolded. This implied a very different perception of the Australian sovereign, including the relationship between politics and citizens.

In the Tampa-related debate about the Border Protection Bill 2001, both sides of Parliament accused the other of adopting their standpoint for electoral gain, 
yet the electorate didn't figure significantly in the debate. ${ }^{33}$ Citizens were neither the object nor the reason for the bill. It was directed at non-citizens and international actors, and arguments focused on domestic legal issues. Clear distinctions were made between citizens' and non-citizens' legal status. This was quite different from earlier discussions about refugee policies. To understand the novelty, I want to revisit the debate on the 'strip-search bill' (the Migration Legislation Amendment [Immigration Detainees] Bill [No. 2] 2001). This was adopted in the Senate on the same day as the Border Protection Bill 2001 was introduced, and had been discussed in the House of Representatives just days before the Tampa debate began. While the bill was adopted after Tampa's arrival, its conception, debate and policy, concerned with issues of immigration detention, belonged to the pre-Tampa doctrine of deterrence by example.

During the debate on the strip-search bill, the situation of non-citizens in detention was discussed indirectly in relation to Australian citizens. At the same time, the question of state power played a significant role in the debate. After all, the bill was introduced to guarantee the authority of the State over refugees within detention centres. Danna Vale (Liberal Party) went so far as to warn the House of Representatives about the dangers that rioting inmates at immigration detention centres posed to Australian sovereignty:

We either uphold the rule of law in Australia - and that is the rule of law for everyone - or we do not. We should all be very much aware that the alternative to an orderly immigration process is immigration that is out of control - and that would be the triumph of chaos over order. ${ }^{34}$

Chaos meant that not everyone, no matter what legal status, was treated the same - an assumption that was shared by those who criticised the incarceration of non-citizens.

An immigration process that was considered 'in order' was the offshore processing of refugee resettlement through the UNHCR and Australia's Immigration Department. In 2001, as in previous years, Australia granted approximately 12000 residence visas on humanitarian grounds. This refugee program was, however, always closely connected to Australia's immigration policy and candidates were selected mostly for their suitability to contribute to Australian society. ${ }^{35}$ Even when the government accepted refugees because of needs identified by the UNHCR, it did so on its own free terms, based on its judgment of social benefit. In this regard, onshore refugees were, on the one hand, condemned for avoiding procedures that were considered Australia's sovereign right-namely, to decide who comes and under what circumstances - while on the other hand, they were evaluated as migrants in their relation to Australian society. In other words, refugee issues were considered a matter of the Australian sovereign, which did not stand solely for 
the State, citizens or non-citizens but appeared to encompass all elements. Vale made this point clear by emphasising 'the rule of law for everyone'. ${ }^{36}$

The central unspoken question was how to define Australian sovereignty if State and citizens were not distinguished from refugees and migrants by their legal status. In comparison with the debate about the Border Protection Bill 2001, the parliamentary debate on the strip-search legislation did not focus so much on sovereignty as on Australia's alleged social character as a whole. This was done with references to collective pasts. Social memories were evoked in arguments, combining elements of sovereignty, power and belonging. As McCalman wrote in her op-ed article, 'understanding of the past...shapes our sense of identity'. 37 Indeed, proponents of memory studies agree that memories contribute to the impression of belonging. Benedict Anderson famously suggested that people remembering a common past imagined a shared communality. ${ }^{38}$

In the debate about the strip-search bill, such communalities were imagined in relation to refugees. Senator Bob Brown (Greens) claimed that immigration detention was 'very similar to the Port Arthur asylum treatment of over 150 years ago'.39 While making a point about the current treatment of asylum-seekers, the reference to Australia's convict history invited listeners to imagine a common past. The condemnation of the historical practice created a form of social belonging based on empathy for those suffering from current 'asylum treatment'. To imagine belonging, however, the considered past must be constitutive to the person remembering instead of just being a historical fact like any other. The individual act of imagining communality, shared by a small number of people, is, contrary to what Anderson suggests, not congruent with the implied community of the memory-all Australians in this case. ${ }^{40}$ The legitimacy of Brown's argument rested on the assumption that the Port Arthur penal station represented a past that was personally important to all Australians. This memory is not, however, relevant to all Australians to whom this memory is supposed to apply, even if it is understood as a historical reference. Belonging is thus created on two levels of memories: the level of those remembering and the level of those imagined in the act of remembering.

The group remembering and the community imagined are not identical. Communal memories are not necessarily shared by all who are considered part of the community. An example of that was given by Senator Jim McKiernan (Labor) in the debate about the strip-search bill. To demonstrate the prejudices existing in the electorate, he read a letter he had received from a member of the public, who argued:

Being a fourth generation Australian it was my ancestors who fought to keep Australia a free country and Christian country for our families. All the deaths of our ancestors in war, I feel now is [sic] in vain and our 
rights as citizens of Australia are being compromised by the influx of refugees. $^{41}$

The imagined Australian community through which the author perceived the contemporary relation to refugees was taken from Australian history. Like McKiernan, however, many Australians would not agree that this imagined community was a legitimate representation of Australia. In other words: communal memories are directed at the whole of the community but they are understood as an expression thereof by the remembering group only.

A multitude of communal memories contest Australia's character in relation to refugees. While many such memories exist simultaneously, they are exclusive in a political context, each claiming to represent the imagined community Australia. Beyond the symbolism of representation, the exclusivity is based on another widely accepted function of memories, which is described by McCalman: they 'guide us in the present and for the future'. ${ }^{42}$ The memories and their imagined communities contest each other not just for the specific ideas of Australia they contain, but because the way they relate this idea to the present situation has explicit political implications. Whether the plight of refugees is equated with Australian experiences or refugees are presented as being opposed to an imagined Christian community has a desired effect on policies towards refugees.

Different memories suggest different interpretations of the present situation and thus different solutions for which they compete. It was in fact the contemporary political situation, the question of how 'Australia' should treat refugees, which evoked memories as expressions of political interests in the first place. Different solutions presented by communal memories compete because they depend on a collective ability to act. In regard to migration and refugee policies, the government, representing the executive power of the sovereign, thus serves as the focus of communal memories. Different versions of the past presented by memories stood for different policies competing in order to be adopted by the executive power for an apparently common good.

Communal memories are justifications of competing political interests within the same political body and claim to represent the current solution for the whole of the political body presented as a community. Communality is imagined as a traditional relationship of its members, veiling the power of the State to which they are commonly subjected. From this viewpoint, belonging is not a question of legal status or of the rights-based relation to the State, but of seemingly shared homogenous values expressed in memories and traditions. Communal memories have the function of bridging the partiality of interest groups by remembering the communality of the government's political action. In fact, it is the power of the State under which members of the imagined community are united and through which partial interests can become common policies. 
In terms of sovereignty, communal memories veil the democratic legal institutions, the legislature and the judiciary, which mediate between citizens and the government as central authority, with a homogenous perception of belonging. Consequently, political interests are discussed in apparently hyper-political and non-partisan terms of communal belonging. The government seems to reflect shared values and to work for an apparently common interest of 'all', representing homogenous sovereignty. The State is therefore confronted in refugee policies with the dilemma of having to act in the name and for the benefit of a disputed community while having to act according to legal distinctions that define and separate refugees. During the Tampa crisis, the past acquired a different function and the way refugees related to the sovereign changed.

\section{Sovereignty and memories (II)}

Before the Tampa crisis refugees were treated like any immigrant, potentially belonging to or being excluded from politically imagined versions of Australia. During the Tampa crisis, this perception changed. Refugees came to be discussed in terms of border protection and of their legal relation to the Australian State. ${ }^{43}$ They were perceived as a threat to Australian sovereignty and were thus confronted at the border with powers apparently unrelated to sovereignty. The

government denied that refugees were humans seeking protection. ${ }^{44}$ Cutting asylum-seekers off from any relation to sovereignty, debates now referred to the past in three new and distinct ways: as governmental memories, as citizenship memories and as universal memories.

The government, making a distinction between sovereignty and its power in dealing with refugees during the Tampa crisis, removed the civic foundation of political action by dividing the imagined community. It still relied, however, on the past or particular versions of it to deal with the problem at hand. It has been overlooked by commentators that Howard often introduced his line about Australia's prerogative to determine who enters the country with references to the past. When he first spoke about the Tampa in the House of Representatives in the early afternoon of 27 August, he said:

Australia has a record in relation to caring for refugees of which every member of this House should be proud. No nation in the last 50 years has been more generous or more decent in relation to refugees than has Australia...But that does not mean that we are abandoning in any way our right to decide who comes here. ${ }^{45}$

Similarly, two days later, he asserted, hours before the Border Protection Bill 2001 was introduced:

Nobody pretends for a moment that the circumstances from which many people flee are not very distressing. But equally, it has to be said that, 
in the last 20 years, no country has been more generous to refugees than Australia. After the Indochinese events of the 1970s, this country took, on a per capita basis, more Indochinese refugees than any other country on earth. We have continued to be a warm, generous recipient of refugees, but we have become increasingly concerned about the increasing flow of people into this country. Every nation has the right to effectively control its borders and to decide who comes here and under what circumstances, and Australia has no intention of surrendering or compromising that right. ${ }^{46}$

These memories of successful immigration policies of the past served to provide a backdrop to evaluate the situation that was unfolding. They are 'governmental memories' because they refer to the previous actions of the government in order to evaluate the current situation.

Such interpretations of past Australian immigration policies were not exclusive to the governing Coalition. In response to the above statement by the Prime Minister, Labor leader, Kim Beazley, reminded the House:

Over the last 10 years something like 13,000 people have come into Australia this way [from Indonesia by boat]: 2,000 up until about 1996 and 11,000 since then. Quite clearly, there is a job of work to be done in terms of our relationship with Indonesia to in some way check or halt this process. ${ }^{47}$

The Leader of the Opposition in the Senate, John Faulkner, introduced his speech about the Border Protection Bill 2001 by saying:

Over the past 10 years, there have been 13,000 unauthorised entries into this country. Eleven thousand of those have occurred since 1996. Labor has consistently supported measures put up by the Howard government to stem this flow of illegal entries. ${ }^{48}$

Much in the same vein as the Coalition, the Labor Party used governmental memories to legitimise its present position.

The past figured in these arguments in order to 'guide us in the present and for the future', just like communal memories described above. The implications of the use of the past are, however, different here. Communal memories are based on a social level while governmental memories are situated exclusively at the level of state politics - in terms of what is remembered and in their political objectives. Instead of imagining a community in a shared past, the latter uses the past to legitimise the assertion of Australia's sovereign right and power to enforce policies.

References to the past functioned as incentives for political action in lieu of the sovereign community: Howard recalled Australia's generosity but said that this 
did not change Australia's 'right to decide who comes here'. Beazley counted recent arrivals of refugees by boat, on which he based his call to 'halt this process'. Faulkner referred to the same past in order to claim that Labor had already assisted the government to 'stem this flow of illegal entries'. The most important words in those arguments are Howard's 'but', Beazley's 'halt' and Faulkner's 'stem'. It is not a traditional past of an imagined community that shapes the policy according to governmental memories; rather, the past is intended to show that it lies within the government's power to determine the action taken in regard to refugees. The past of governmental memories is a showcase for state power making history.

When the government initiated its new refugee policy of deterrence by force, it separated state power not only from universal rights but from citizenship. This prompted a new perception of sovereignty that redefined its relationship to refugees and the role of the past in political arguments. Governmental memories figured as justification for state power being autonomous from legal checks and balances and from traditions imagined as communal sovereignty. The new perception of sovereignty and of the past was not, however, limited to governmental memories. Others responded to the new policy situation with the same new perception of sovereignty; but instead of focusing on the government's power, they highlighted the other separated elements of sovereignty: citizenship and universality.

Since Australian society was not perceived as an all-encompassing community anymore, citizenship memories offered a different possibility to relate refugees to Australians. Senator Nick Bolkus (Labor) suggested:

In that context, you really have an obligation to help those who want to come here as refugees and in humanitarian circumstances - if for no other reason than, in looking back at our history, it can be seen that those who have come here over the years as refugees have made enormous contributions to this country. They have not stagnated and have not been stillborn in their citizenship of Australia. They moved on one after the other and contributed enormously. We have met social responsibilities but, as a nation, we have benefited from those whom we brought in in these circumstances. ${ }^{49}$

Instead of relating refugees to an imagined Australian community, they are evaluated by past actions considered useful to the citizenry. Based on citizenship memories, refugees are judged as equal parts of Australian society rather than as traditionally different or similar. With citizenship being distinguished from state power, however, these memories are not able to relate refugees to the protective power of the sovereign. Refugees remain removed from the State's civil protection and from asylum under international obligations. Society is 
viewed retrospectively by citizenship memories as being bound neither by communal belonging nor by legal status but by civil action and social usefulness. Finally, universal memories relate policies to global events and human rights. ${ }^{50}$ In the debate about the Border Protection Bill 2001, Senator Andrew Bartlett (Australian Democrats) recalled stories of refugee boats during the twentieth century: he reminded his audience that the passengers of the St Louis, the Strumer and the Petchko all died or were deported to concentration camps because their vessels were turned away. He also recalled that hundreds of thousands of people fleeing Vietnam 'died during their doomed journey to freedom' ${ }^{51}$ He concluded:

That was an inevitable outcome of the situation that developed when countries sent out the message that they would not be willing to accept people that they knew would be asylum seekers and sent them on and said: 'You have to go somewhere else. It is someone else's problem. It is someone else's responsibility.' ${ }^{52}$

These memories were directed at the Australian State to act according to a set of humanitarian principles. They reminded the audience of universal historical events: of the Holocaust and of the Vietnam War. These memories were not supposed to represent sections of Australian citizenry; instead, their implications were universal and applied to every sovereign, not just to the Australian State and people.

Universal memories point out the rights of man according to which refugees are supposed to be treated as 'humans', and call for humanitarian action. The Democrats therefore protested by calling on the past against the government's strategy of stripping asylum-seekers of their human right to claim asylum under a sovereign power. They appealed, however, not to the sovereign's responsibility but to universal morality. By referring to refugees through events historically unrelated to Australia, the Democrats accepted the separation of universal rights from sovereignty that was evoked by the government's policy with regard to the Tampa.

With the change of memories in the Tampa crisis, the relationship of sovereignty and refugees changed dramatically. Before Tampa, the sovereign seemed to act as one traditional community that was marked off clearly from the universal status of refugees. During the Tampa debate, the imagined community that represented Australian sovereignty was split into separate elements: state power, citizenship and universal rights. These elements of sovereignty were represented by different references to the past, which all failed to represent sovereignty in themselves: in governmental memories, state power seemed to exist isolated from sovereignty just like citizens in citizenship memories and human rights in universal memories. Consequently, these memories fail to relate refugees to sovereignty. Instead, they connect refugees to Australia and to political action 
in different ways: as objects of government action, of civil action or of humanitarian action. While, however, the different uses of the past allowed different approaches to refugees, the dilemma of sovereign political action in respect to asylum-seekers - the obligation of universal sovereignty - was not solved but only shifted.

Before Tampa, the government did not act on the obligation of asylum because the communal perception of sovereignty ignored the distinction of legal status on which refugees might have been able to claim asylum. After Tampa, refugees were related merely to elements of sovereignty, which prevented the full recognition of their legal status in Australia as asylum-seekers and subjected them to arbitrary forms of political power and action. After analysing the shift during the Tampa crisis in regard to memory, sovereignty and refugees, a closer look needs to be taken at what the change entailed and how the before and after relate in order to understand the impact of this event on Australian politics.

\section{Sovereignty and refugees (II)}

In Australian politics, the arrival of the Tampa was a key event that led to the modification of deterrence by example to deterrence by force, altering the significance of different forms of memory in parliamentary debates and, simultaneously, the relation of sovereignty to the issue of refugees. Shifting the debate of refugee issues from their treatment in immigration detention to border protection, the government's focus moved from the Australian community to state power. This enabled the Howard Government to move forward with the refugee issue in terms of governing.

The past became a reference for change enforced by state action, instead of legitimising social traditions to deter change. The failed policy of deterrence by example, having argued for refugee policies based on perceptions of communal traditions, seemed to be stuck in the past-virtually and literally. Memories, which imagine a community by looking back, derive solutions to political challenges from the logic of an imagined tradition. The strength of such memories is to create the impression of communal belonging, which apparently encompasses all citizens who seem to act jointly through the State. Post-Tampa memories, instead, isolated citizens from each other and from the State. The government now appeared to have powers in regard to the present situation that were autonomous of citizens, of the international sphere and of traditions. It looks back to create a future different from the past. Taking a new stance on refugees in the Tampa crisis, the government adjusted its memories and therefore its understanding of the present situation - namely, sovereignty and refugees.

So far, I have differentiated between concepts of memory and sovereignty before and after the Tampa's arrival. Despite the clear changes, communal and governmental memories always coexist and only their respective significance 
changes. $^{53}$ The debates pre- and post-Tampa were distinct but all forms of memory can be found at any stage of the Australian debate about refugees. Governmental memories were used in the debate about the strip-search bill and much earlier. Conversely, memories uniting citizens and power in an imagined community played a role after Tampa, albeit a much less important one than before. Having differentiated the two phases before and after Tampa allowed me, however, to set apart ideal-type categories of memory and concepts of sovereignty. The forms of memories need to be recognised in order to understand the change precipitated by the Tampa crisis.

Memories pre- and post-Tampa are not simply opposed and unrelated. Both forms of memory have in common that they veil the mediation between citizens and the State. In the case of communal memories, citizens and the State are unmediated in a traditionally and homogenously defined sovereignty. In governmental memories, citizens and the State are separated as non-mediated elements of sovereignty. In both cases, human rights seem separated from the concepts of sovereignty. The politics of sovereign countries, however, rest on universal rights, sovereign citizens and sovereign power. The government derives its power from the universally accepted concept of a sovereign population within a territory while citizens are only citizens as humans and as subjects of the sovereign power. The significance of both forms of memory within the polity, however, focused on community or on the State, changes along with the relevance of the elements of sovereignty in relation to current politics. Not only politicians' perception, but the population's perception of the past and of society changed rapidly with the new politics in regard to the Tampa.

When the Howard Government attempted to distinguish between governmental force and sovereign citizenship by separating sovereign territory from the migration zone and introducing Operation Relex - the removal of unwanted ships from territorial waters - it revealed the brutality of a power unchecked by civil and human rights. ${ }^{54}$ This approach was initiated by the SAS assault on the Tampa. With the government tackling the refugees aboard the Norwegian ship, the standing of the Liberal Party in the polls improved almost instantly. The electorate immediately grasped the new political situation proposed by the government in relation to the Tampa and many voters changed their perception of politics accordingly. In relation to border control, Australians no longer saw themselves as members of a community, potentially open to those who were willing to share certain Australian memories and values. Instead, their view 'turned inwards', as Mackay had predicted, to focus on citizenry and civil society. Letters to newspapers, such as this one from Joan Bidio to the Herald Sun, can be taken as evidence of the new perspective: 'Perhaps the humanitarian civil liberties groups and others of like mind could now turn their indignant attention to helping ordinary Australians such as the homeless, the struggling poor, basic pensioners and those in nursing homes. ${ }^{55}$ Refugees and 
asylum-seekers were not connected to Australia anymore, either as part of a multicultural society or as 'others', but were excluded as non-citizens.

Conversely, Australians, in the new perception of a divided sovereignty, were isolated as citizens, isolated from the international sphere and separated from their sovereign power. In the former perception of Australia, the State was an indistinguishable part of the homogenous imagined community. After Tampa, the State and citizens emerged as distinct and separate elements. This change seemed to empower the State, which was no longer hindered either by civil sovereignty or by international obligations. Citizens now perceived themselves, however, as disempowered, isolated and insecure. The government's decision to change its approach to refugees simultaneously created its appeal as a protective power to citizens. Refugees, as objects of the government's action, were blamed for the insecurity stemming from that same change of politics. They appeared as a threat, and the government was applauded for tackling them with force.

That the support for the new policy often took on racist undertones was a sign that traditions of White Australia persisted in society as communal memories. ${ }^{56}$ They influenced people's perception despite a change-oriented and state-centred use of the past, which dominated the debate. Governmental memories structured the new public perception of politics while communal categories of cultural inclusion and exclusion underlaid the political interests. Politics transformed not memories altogether but the relationship of governmental and communal memories. Only through the interplay of different forms of memory, and their specific perceptions of sovereignty, can the changes that occurred during the Tampa crisis be understood: governmental memories gained greater public relevance over communal memories in the formulation of policies, and the political significance of the perception of sovereignty shifted, associating Australia in a new relation to refugees.

The political crisis embodied in the Tampa incident, for which refugees were blamed, was not the fault of refugees, but was inherent in the contradiction and fiction of sovereignty. While citizens appeal to the State for protection from external threats, fundamental rights vis-a-vis the State are based on their equality as humans. Sovereignty as a political foundation is challenged not only in relation to asylum-seekers. It is, as a contradiction of the sovereign citizenry, the sovereign state and universal human rights, a fiction to begin with. Refugees demonstrate, no more and no less, this critical state of a world organised by sovereignties. Their existence undermines the illusion of harmonious power relations imagined in communal memories. They become the disturbing representation of the inherent crisis of any state system. They are therefore either futilely repelled with force by proponents of state power or supported as a seemingly positive challenge to power by critics of the State. 


\section{Conclusion}

Refugees coming by boat, even in their thousands, were and are no threat to Australia's security. Lacking the protection of their own nation-state and possessing nothing more than their humanity, they are perceived as a challenge to the political sovereign. The response to their arrival is dependent on the perception of sovereignty, of the past and the present.

In this chapter, I have outlined how the Tampa crisis changed popular perceptions of refugees, citizens and the State. Before Tampa, sovereignty, which binds citizenship, the State and universal rights, was united in society by references to the past - a past to which refugees could be related as migrants. Those memories allowed social belonging to be imagined as community, which had to be sustained. With the arrival of the Tampa, the expectation that the State could deter refugees by force led the government to disaggregate the sovereign polity into state power, citizenship and universal rights. Memories no longer bound society but were related instead to refugees, the State or citizenship. The alteration of sovereignty and memory allowed the government to move beyond the failed policy of deterrence by example. The perception of the past shifted in a way that excluded refugees by their very definition as non-citizens from a newly perceived Australian society. ${ }^{57}$ All the while, Australia found itself caught up in an impossible policy of pure force.

Focusing on the interplay of different concepts of memory, this chapter challenges static conceptions of sovereignty. It has shown how policies based on this idea affect images of belonging, which in turn influence refugee policies. Policies based on sovereignty, however, are not compatible with the needs of stateless asylum-seekers. That refugees are the object of sovereign power is a reminder that sovereignty based on any form of the past is always an exclusive concept of power. Refugees could be accommodated only if sovereignty was built on the memory of statelessness.

\section{Acknowledgments}

I would like to thank Klaus Neumann, Gwenda Tavan and Tai Sayarath for important comments, criticism and advice on several draft versions of this chapter. Of course, none of them should be held accountable for any deficiencies of the text, which are wholly my responsibility. I wrote this chapter while a visiting scholar at the Institute for Social Research at Swinburne University of Technology. The Friedrich Ebert Foundation supported my work with a postgraduate scholarship. 


\section{Endnotes}

${ }^{1}$ Halbwachs, Maurice 1980 [1950], The Collective Memory, Translated by Francis J. Ditter, Jr, and Vidar Yazdi Ditter, Harper \& Row, New York, p. 86.

2 Davidson, Alastair 1997, From Subject to Citizen: Australian citizenship in the twentieth century, Cambridge University Press, Cambridge, p. 150.

3 Mackay, Hugh 2001, 'Politics fans the flames of ugly prejudice', Age, 25 August 2001.

4 Subsequently, that rhetoric became the focus of several studies; see, for example, Corlett, Dave 2002, 'Asylum seekers and the new racism', Dissent, vol. 8; Every, Danielle and Augoustinos, Martha 2007, 'Constructions of racism in the Australian parliamentary debates on asylum seekers', Discourse Society, vol. 18 , no. 4 .

5 Hage, Ghassan 1998, White Nation: Fantasies of white supremacy in a multicultural society, Pluto, Sydney; Markus, Andrew 2002, 'Racism and refugees: an Australian tradition', Australian Rationalist, vols 60-1. Numerous works from different perspectives have dealt with the Tampa crisis as a pivotal point in Australian politics - most importantly, Marr, David and Wilkinson, Marian 2003, Dark Victory, Allen \& Unwin, Crows Nest; and Mares, Peter 2002, Borderline: Australia's response to refugees and asylum seekers in the wake of the Tampa, UNSW Press, Sydney, ch. 5.

6 Agamben, Giorgio 1998, Homo Sacer: Sovereign power and bare life, Stanford University Press, Stanford, pp. 15-70.

7 McCalman, Janet 2001, 'Teaching history safeguards the truth', Age, 25 August 2001.

8 Olick, Jeffrey K. and Robbins, Joyce 1998, 'Social memory studies: from "collective memory" to the historical sociology of mnemonic practices', Annual Review of Sociology, vol. 24.

9 The classic and still one of the most concise concepts of social memory is Halbwachs, Maurice 1992, On Collective Memory, Translated by Lewis A. Coser, University of Chicago Press, Chicago. See also Halbwachs, The Collective Memory.

10 Brändström, Annika, Bynander, Fredrik and 't Hart, Paul 2004, 'Governing by looking back: historical analogies and crisis management', Public Administration, vol. 82, no. 1, pp. 191-210.

11 Ruddock, Philip 2001, 'Detention contingency planning announced', MPS 123/2001, 23 August 2001.

12 Marr and Wilkinson, Dark Victory, p. 61.

13 Mares, Peter 2007, 'Reassessing the Tampa', in Dan Lusher and Nick Haslam (eds), Yearning to Breathe Free: Seeking asylum in Australia, Federation Press, Annandale, pp. 58-9.

14 Australia's cooperation with Indonesia in matters of policing the borders, and later, the government's hope to cooperate with Norway on the Pacific Solution were other attempts of using the recognition of sovereignty to contain border breaches (Marr and Wilkinson, Dark Victory, pp. 38-61 and 160-2).

15 Ibid., pp. 88-9.

16 Philip Ruddock, Commonwealth Parliamentary Debates [hereafter CPD], Representatives, 28 August 2001, p. 30362.

17 Ruddock, Philip 2001, 'Successful removal of 31 People from Australia', MPS 128/2001, 28 August 2001.

18 John Howard, CPD, Representatives, 27 August 2001, p. 30235.

19 Marr and Wilkinson, Dark Victory, pp. 108-9.

20 UNHCR 1981, Problems related to the rescue of asylum-seekers in distress at sea, EC/SCP/18.

21 Pallis, Mark 2002, 'Obligations of states towards asylum seekers at sea: interactions and conflicts between legal regimes', International Journal of Refugee Law, vol. 14, nos 2-3.

22 The last point was especially odd as the migration zone did not extend to the territorial sea like the sovereign power did; see Hancock, Nathan 2001-02, 'Border Protection Bill 2001', Bills Digest, vol. 41, Department of the Parliamentary Library, p. 13.

23 John Howard, CPD, Representatives, 29 August 2001, p. 30570.

24 Robert Hill, CPD, Senate, 29 August 2001, p. 26976.

25 Kim Beazley, $C P D$, Representatives, 29 August 2001, p. 30571.

26 Bob Brown, CPD, Senate, 29 August 2001, p. 26996.

27 Arendt, Hannah 1994 [1948], The Origins of Totalitarianism, Harcourt, San Diego, pp. 269-302.

28 Agamben, Giorgio 1995, 'We refugees', Symposium, vol. 49, no. 2, p. 117. 


\section{Does History Matter?}

29 High Court, Chu Kheng Lim vs MILGA [1992], 110 ALR 97. Mary Crock highlights the critical distinction between civic and international law made by the court in its ruling. Crock, Mary 1993, 'Climbing Jacob's ladder: the High Court and the administrative detention of asylum seekers in Australia', Sydney Law Review, vol. 15.

30 The refugees had to reach the migration zone, which did not include the territorial sea, in order to claim asylum. Alternatively, they could have claimed asylum through an Australian official. Refugees aboard the Tampa were prevented from lodging asylum claims with relevant Australian authorities and from receiving legal representation (Marr and Wilkinson, Dark Victory, pp. 145-68).

31 John Faulkner, $C P D$, Senate, 29 August 2001, p. 26973; Natasha Stott Despoja, CPD, Senate, 29 August 2001, pp. 26979, 26980, 26982; Andrew Bartlett, $C P D$, Senate, 29 August 2001, p. 26995; Nick Bolkus, $C P D$, Senate, 29 August 2001, p. 26998.

32 Robert McClelland, CPD, Representatives, 19 September 2001, p. 30965. The Pacific Solution was the result of legislation that was debated in Parliament between 18 and 26 September 2001: the Migration Amendment (Excision from Migration Zone) Bill 2001, the Migration Amendment (Excision from Migration Zone) (Consequential Provision) Bill 2001 and the Border Protection (Validation and Enforcement Powers) Bill 2001. The bills included the extended distinction between migration zone and territory, detention in foreign countries and removal of boats from territorial waters, of which the last provision had been rejected in its previous form on 29 August 2001.

33 Examples of those accusations are statements by Robert Hill: 'The opposition in these circumstances apparently believes that it can get some benefit through not supporting the government today in this difficult time, so be it' (CPD, Senate, 29 September 2001, p. 26968); and by Labor's Nick Bolkus: 'My fear is that the Prime Minister is playing politics with the national interest. It diminishes his reputation, although he does not seem to care about that when votes and his hide are at risk' ( $C P D$, Senate, 29 August 2001, p. 26999).

34 Danna Vale, $C P D$, Representatives, 23 August 2001, p. 30112.

35 Neumann, Klaus 2007, 'Been there, done that?', in Dean Lusher and Nick Haslam (eds), Yearning to Breathe Free: Seeking asylum in Australia, Federation Press, Annandale, p. 27; Neumann, Klaus 2004, Refuge Australia: Australia's humanitarian record, UNSW Press, Sydney.

36 Danna Vale, $C P D$, Representatives, 23 August 2001, p. 30112.

37 McCalman, 'Teaching history safeguards the truth'.

38 Anderson, Benedict 1991, Imagined Communities, 2nd edn, Verso, London, pp. 199-203.

39 Bob Brown, CPD, Senate, 28 August 2001, p. 26822.

40 Anderson (Imagined Communities, pp. 200-1) notes about the nineteenth-century French community, imagined in memories of 'la Saint-Barthélemy', that not every French person would have remembered this past. Anderson fails, however, to distinguish between those who remembered and the much larger group of those who were included in the imagination. Instead, he suggests - not quite coincidentally, as I argue - that 'the state' reminded every French person of the shared history, presenting the notion of 'French' as the beginning and the end point of memories.

41 Quoted by Jim McKiernan, CPD, Senate, 28 August 2001, p. 26820.

42 McCalman, 'Teaching history safeguards the truth'.

43 Jeremy Hein, who takes this legal perspective, argues accordingly that the relation to the State is what distinguishes the refugee from other migrants. Hein, Jeremy 1993, 'Refugees, immigrants, and the state', Annual Review of Sociology, vol. 19, no. 1.

44 In order to prevent Australians from recognising refugees as fellow humans, the government tried to restrict the circulation of any humanising photographs of refugees aboard the Tampa (Marr and Wilkinson, Dark Victory, p. 108).

45 John Howard, $C P D$, Representatives, 27 August 2001, p. 30235.

46 John Howard, CPD, Representatives, 29 August 2001, pp. 30517-8.

47 Kim Beazley, $C P D$, Representatives, 29 August 2001, p. 30519. For a very similar statement in the debate about the Border Protection Bill 2001 debate, see $C P D$, Representatives, 29 August 2001, p. 30572 .

48 John Faulkner, CPD, Senate, 29 August 2001, p. 26971.

49 Nick Bolkus, CPD, Senate, 29 August 2001, p. 26998.

50 Daniel Levy and Nathan Sznaider have also used the term 'universal memory' to describe trends in Holocaust memory and in regard to the 'cosmopolitan morality' of human rights. The authors argue 
that universal Holocaust memories stand at the beginning of institutional human rights. Today, universal memories are part of what they call 'cosmopolitan memory', which includes the partiality of its application in the genocide discourse. Levy, Daniel and Sznaider, Nathan 2004, 'The institutionalization of cosmopolitan morality: the Holocaust and human rights', Journal of Human Rights, vol. 3, no. 2. The use of memory to call on human rights is, however, not exclusive to Holocaust memories - see, for example, the reference to Vietnam below. Furthermore, the term 'cosmopolitan memory' merges the universal with what is considered partial memory without mediation. I argue instead that it is the distinction of different forms of references to the past - universal, governmental and citizenship memories - that helps to explain the current relevance of what seems to be cosmopolitan memory and which also shows the limitations of memories in regard to human rights.

51 Andrew Bartlett, $C P D$, Senate, 29 August 2001, pp. 26994-5.

52 Ibid., p. 26995.

53 This relationship is based on the dialectics of 'abstract time' and 'historical time', suggested by Moishe Postone as an explanation for the 1970s transformation of Holocaust memories. Postone, Moishe 2003, 'The Holocaust and the trajectory of the twentieth century', in Moishe Postone and Eric L. Santner (eds), Catastrophe and Meaning: The Holocaust and the twentieth century, University of Chicago Press, Chicago, pp. 102-6.

54 The danger of separating power - in Operation Relex, it was naval power - from notions of sovereignty was incidentally seen by the Navy itself, which warned of the brutal consequences of such an approach (Marr and Wilkinson, Dark Victory, pp. 172-6).

55 Bidio, Joan 2001, 'Letter to the editor', Herald Sun, 7 September 2001.

56 Jayasuriya, Laksiri, Walker, David and Gothard, Jan (eds) 2003, Legacies of White Australia: Race, culture and nation, University of Western Australia Press, Crawley, especially chapters by Ien Ang, Robert Manne and Andrew Markus. The legacies of White Australia are also debated in Tavan, Gwenda 2005, The Long, Slow Death of White Australia, Scribe, Melbourne, pp. 221-33.

57 This is different from assuming a shift in the Tampa crisis from an inclusive to an exclusionary model of citizenship as suggested by Kim Rubinstein. Rubinstein, Kim 2002, 'Citizenship, sovereignty and migration: Australia's exclusionary approach to membership of the community', Public Law Review, vol. 13, pp. 102-9. 